\title{
Dramatic Inner-Core Tropopause Variability during the Rapid Intensification of Hurricane Patricia (2015)
}

\author{
PATRICK DURAN AND JOHN MOLINARI \\ Department of Atmospheric and Environmental Sciences, University at Albany, State University of New York, \\ Albany, New York
}

(Manuscript received 25 July 2017, in final form 31 October 2017)

\begin{abstract}
Dropsondes with horizontal spacing as small as $4 \mathrm{~km}$ were released from the stratosphere in rapidly intensifying Hurricane Patricia (2015) during the Office of Naval Research Tropical Cyclone Intensity experiment. These observations provide cross sections of unprecedented resolution through the inner core of a hurricane. On 21 October, Patricia exhibited a strong tropopause inversion layer (TIL) across its entire circulation, with a maximum magnitude of $5.1 \mathrm{~K}(100 \mathrm{~m})^{-1}$. This inversion weakened between 21 and 22 October as potential temperature $\theta$ increased by up to $16 \mathrm{~K}$ just below the tropopause and decreased by up to $14 \mathrm{~K}$ in the lower stratosphere. Between 22 and 23 October, the TIL over the eye weakened further, allowing the tropopause to rise by $1 \mathrm{~km}$. Meanwhile over Patricia's secondary eyewall, the TIL restrengthened and bulged upward by about $700 \mathrm{~m}$ into what was previously the lower stratosphere. These observations support many aspects of recent modeling studies, including eyewall penetration into the stratosphere during rapid intensification (RI), the existence of a narrow inflow layer near the tropopause, and the role of subsidence from the stratosphere in developing an upper-level warm core. Three mechanisms of inner-core tropopause variability are hypothesized: destabilization of the TIL through turbulent mixing, weakening of the TIL over the eye through upper-tropospheric subsidence warming, and increasing tropopause height forced by overshooting updrafts in the eyewall. None of these processes are seen as the direct cause of RI, but rather part of the RI process that includes strong increases in boundary layer moist entropy.
\end{abstract}

\section{Introduction}

Hurricane Patricia became the strongest recorded hurricane in the Western Hemisphere after undergoing remarkably rapid intensification (RI) between 21 and 23 October 2015 (Kimberlain et al. 2016; Rogers et al. 2017). Throughout this RI period, a NASA WB-57 aircraft flying in the stratosphere deployed 244 dropsondes as part of the Office of Naval Research Tropical Cyclone Intensity (TCI) Experiment (Doyle et al. 2017). These dropsondes revealed dramatic changes in upper-level static stability and cold-point tropopause structure throughout Patricia's RI.

The cold-point tropopause is defined as the level of minimum temperature in a sounding (Highwood and Hoskins 1998). This tropopause definition is widely used in the tropics because the cold-point temperature influences the exchange of ozone and water vapor between the troposphere and stratosphere (Mote et al. 1996), which has important climatological implications (Holton

Corresponding author: Patrick Duran, pduran@albany.edu et al. 1995). Although few papers have analyzed the effect of tropical cyclones (TCs) on the tropopause, radar observations suggest that TCs can enhance tropospherestratosphere exchange through deep convection and turbulent mixing (Das et al. 2008). In addition, Davis et al. (2014) noted that convection within intensifying tropical disturbances can penetrate up to or above the cold-point tropopause, acting to decrease its temperature.

Tropopause temperature is an important parameter in theoretical models of TC structure and intensity. Emanuel and Rotunno (2011) expressed the maximum gradient wind speed at the top of the TC boundary layer as a function of upper-level outflow temperature. They argued that the outflow-layer stratification is determined by a requirement that the Richardson number remains near a critical value for turbulence. Emanuel (2012) further showed that vortex amplification is a function of the radial gradient of outflow temperature, which is determined by small-scale turbulent mixing. Thus, within this theoretical framework, uppertropospheric thermodynamics plays a fundamental 
role in determining vortex structure and evolution. From a climate perspective, changes in tropopause temperature could modify the theoretical maximum intensity that a TC can attain. Emanuel et al. (2013) noted that recent increases in potential intensity [as defined by Bister and Emanuel (1998)] observed in the North Atlantic region can be explained by observed decreases in temperature near the tropopause.

Despite its potential importance, most analyses of TC tropopause structure are decades old. Jordan and Jordan (1954) composited radiosonde ascents through many storms, finding that the tropopause near the storm center was both higher and colder than the surrounding region. In a case study of four landfalling hurricanes using radiosonde composites, Koteswaram (1967) likewise found an elevated and anomalously cold tropopause at innermost radii in three of the storms. The one storm that did not have an anomalously cold tropopause [Arlene (1963)] was weakening as it recurved northward. Koteswaram (1967) argued that the upper-level cold anomaly in the three storms was produced by convection overshooting its level of neutral buoyancy. These radiosonde studies produced analyses of high vertical resolution, but with the drawback of low horizontal resolution. This precluded a detailed analysis of finescale horizontal variability in the upper levels of TCs.

A number of aircraft reconnaissance flights in the 1960s observed very strong horizontal temperature gradients in the inner core of hurricanes. Penn (1966) noted that the tropopause over Hurricane Isbell (1964) sloped upward toward the storm's inner core by $1.1 \mathrm{~km}$ over a $231.5-\mathrm{km}$ horizontal distance. This elevated tropopause was associated with horizontal temperature gradients as large as $5^{\circ} \mathrm{C}(18.5 \mathrm{~km})^{-1}$ in the lower stratosphere. The coldest temperatures, $-85^{\circ} \mathrm{C}$, were observed in the regions of most intense convection. Likewise in Hurricane Beulah (1967), the coldest temperature, $-86^{\circ} \mathrm{C}$, was observed a few hundred meters above the highest cloud tops (Waco 1970). Very near the storm center, the temperature at $16.5-\mathrm{km}$ altitude increased from $-86^{\circ}$ to $-77^{\circ} \mathrm{C}$ over a horizontal distance less than $30 \mathrm{~km}$ as the aircraft approached the storm center [see Fig. 2 "Run 2" in Waco (1970)]. This strong inward temperature increase was likely associated with an intense upper-tropospheric warm core within and near Beulah's eye.

The presence of a warm core in the upper troposphere of hurricanes was documented by a series of studies (La Seur and Hawkins 1963; Hawkins and Rubsam 1968; Hawkins and Imbembo 1976) using aircraft observations. Hawkins and Imbembo (1976, their Fig. 6) depicted two anomalous warming maxima-one centered near $600 \mathrm{mb}(1 \mathrm{mb}=1 \mathrm{hPa})$ and another centered near
$300 \mathrm{mb}$ - in Hurricane Inez (1966). The precise location of these warm cores cannot be known with certainty, however, since data were collected at only four levels: $750,650,500$, and $180 \mathrm{mb}$. The upper-level warm core was recognized at least as early as Haurwitz (1935), who attributed its formation to subsidence warming. Although a number of authors (e.g., Malkus 1958; Willoughby 1979; Smith 1980) have described this subsidence in theoretical models, its precise effect on warmcore structure is still not fully understood.

Until recently, it was widely accepted that the midlevel warm anomaly observed by Hawkins and Imbembo (1976) was a departure from the typical TC warm-core structure, and that TCs are typically characterized by an upper-level warm core. Idealized simulations recently conducted by Stern and Nolan (2012), however, challenged this perspective. Although an upper-level perturbation temperature maximum was observed in many of their simulations, all of them exhibited a midlevel temperature anomaly of higher magnitude. Their results were consistent with Halverson et al. (2006), who observed with dropsondes a maximum temperature anomaly in the midlevels of Hurricane Erin (2001). Potential temperature $(\theta)$ budgets computed by Stern and Zhang (2013) stressed the importance of the vertical profile of static stability in determining the warm core's precise structure. Although mean descent within the eye maximized in the 12-13-km layer, subsidence warming was not large there because the static stability was small. Rather, the maximum temperature anomaly developed in the midtroposphere, where static stability reached a local maximum. A secondary warming maximum existed near the tropopause, where weaker subsidence coincided with larger static stability in the tropical tropopause layer. These results are consistent with Ohno and Satoh (2015), whose idealized simulations exhibited a dramatic increase in upper-tropospheric $\theta$ toward the end of a TC's intensification. Sawyer-Eliassen diagnostics (Pendergrass and Willoughby 2009) revealed that the contribution of balanced dynamics to the upper-tropospheric warming was dominated by the response to latent heating within the eyewall. This response was more pronounced later in the period when the vortex grew upward and inertial stability increased in the lower stratosphere, where static stability was large. Zhang and Chen (2012) likewise argued that increasing inertial stability concentrated downdrafts in the highly stable lower stratosphere, leading to strong adiabatic warming in this layer. In numerical simulations, the upper-tropospheric subsidence appears to be related to a narrow inflow layer in the lower stratosphere. Chen and Zhang (2013) and Chen and Gopalakrishnan (2015) assert the importance 
of the inward advection of higher lower-stratospheric $\theta$ values from outer radii by this inflow layer in developing the upper-tropospheric warm core. Kieu et al. (2016), on the other hand, did not find evidence for inward $\theta$ advection; rather, they stressed only the importance of subsidence warming as the inflow layer turned downward in the inner core (their Fig. 11a).

Although none of these authors explicitly analyzed the inner-core tropopause variability, the simulations of Ohno and Satoh (2015) did show decreased static stability in the lower stratosphere over the eye after the upper-level warm core developed (their Figs. 9c and 10c). Meanwhile outside of the eye, the static stability just above the tropopause increased as the storm intensified. The development of this shallow layer of large static stability is consistent with a few early observations of strong, vertically confined temperature inversions just above the tropopause. An aircraft in Hurricane Beulah (1967) observed a $7^{\circ} \mathrm{C}$ temperature increase in a vertical layer less than $100 \mathrm{~m}$ deep just above the cloud top east of the eye (Waco 1970). Likewise in Hurricane Isbell (1964), the temperature increased by about $8^{\circ} \mathrm{C}$ in a layer shallower than $300 \mathrm{~m}$ [see Fig. 5 in Gentry (1967)]. It is unclear whether these strong inversions were a consequence of the hurricane's presence or if the inversions were a part of the background environment.

More recent literature (e.g., Wirth 2003) has noted that strong, shallow temperature inversions immediately above the cold-point tropopause are a common feature in the tropics, now known as the tropopause inversion layer (TIL). On the planetary scale, TIL formation and maintenance has been tied to planetary wave dynamics (Grise et al. 2010) and vertical gradients of radiative heating across the tropopause (Randel et al. 2007), but the relative contributions of dynamics and thermodynamics remains uncertain (Ferreira et al. 2016). To our knowledge, no paper has examined how hurricanes affect the TIL, although the simulations of Ohno and Satoh (2015) provide some evidence that they can considerably alter the static stability near the tropopause.

The importance of tropopause temperature in theoretical models of TCs, combined with the potential role of static stability in determining the precise structure of the warm core, motivates a closer look at the evolution of the tropopause and static stability in a hurricane. This paper uses a new, high-resolution dropsonde dataset collected during TCI to analyze Hurricane Patricia's upper-level thermodynamic evolution during RI.

\section{Data and methods}

The High-Definition Sounding System (HDSS) provides a new capability to deploy and track up to
40 expendable digital dropsondes (XDDs) simultaneously. This capability permits the rapid deployment of many dropsondes, providing cross sections of pressure, temperature, humidity, and wind velocity with unprecedented horizontal resolution. Black et al. (2017) report that XDDs are able to resolve atmospheric features in a manner comparable to RD-94 dropsondes (Hock and Franklin 1999), operational rawinsondes, and aircraft spiral profiles. The XDDs exhibited a warm bias of $1{ }^{\circ} \mathrm{C}$ and a dry bias of $5 \%$ relative to RD-94 dropsondes. XDD thermodynamic measurements, like those of other in situ sounding instruments, were noisy and unreliable when the sensors became wet. An intensive quality control procedure (Bell et al. 2016) removed unrealistic temperature and humidity observations that likely reflected sensor wetting, as well as relative humidity recorded at temperatures below $-40^{\circ} \mathrm{C}$, where humidity measurements were inaccurate because of slow sensor response time. A more complete description of HDSS's specifications and error characteristics can be found in Black et al. (2017) and Doyle et al. (2017), and a comprehensive description of the quality control procedure in Bell et al. (2016).

Flying near $18.5-\mathrm{km}$ altitude aboard the NASA WB-57 aircraft, HDSS deployed dropsondes with horizontal spacing as small as $4 \mathrm{~km}$ in the inner core of TC Patricia. This dataset builds upon that of the high-altitude dropsonde observations collected by the NASA Hurricane and Severe Storm Sentinel (HS3) investigation (Braun et al. 2016). Although many dropsondes were deployed during each HS3 flight, the typical spacing of 50-200 km was not sufficient to resolve the inner core of a hurricane. In contrast, the average dropsonde spacing for the four complete transects that TCI conducted through the center of TC Patricia ranged from 4.4 to $8.0 \mathrm{~km}$. These four flight legs, shown in Fig. 1, will be used to analyze the upper-tropospheric and lower-stratospheric evolution of TC Patricia during its RI.

The infrared (IR) brightness temperature images plotted in Fig. 1 were parallax-corrected using Man computer Interactive Data Access System (McIDAS-X; Lazzara et al. 1999), assuming a cloud-top height of $15 \mathrm{~km}$. For each transect, the parallax adjustment was determined at every dropsonde position and the IR image was shifted by the average of these adjustment factors. This effectively shifted the IR image $9 \mathrm{~km}$ to the southeast on 21 October (when the satellite image came from GOES-13) and $13 \mathrm{~km}$ to the southwest on 22 and 23 October (when the satellite image came from GOES-15). This parallax adjustment was performed only to show more realistic dropsonde deployment locations relative to the IR brightness temperatures in Fig. 1; it did not impact any calculated field. 

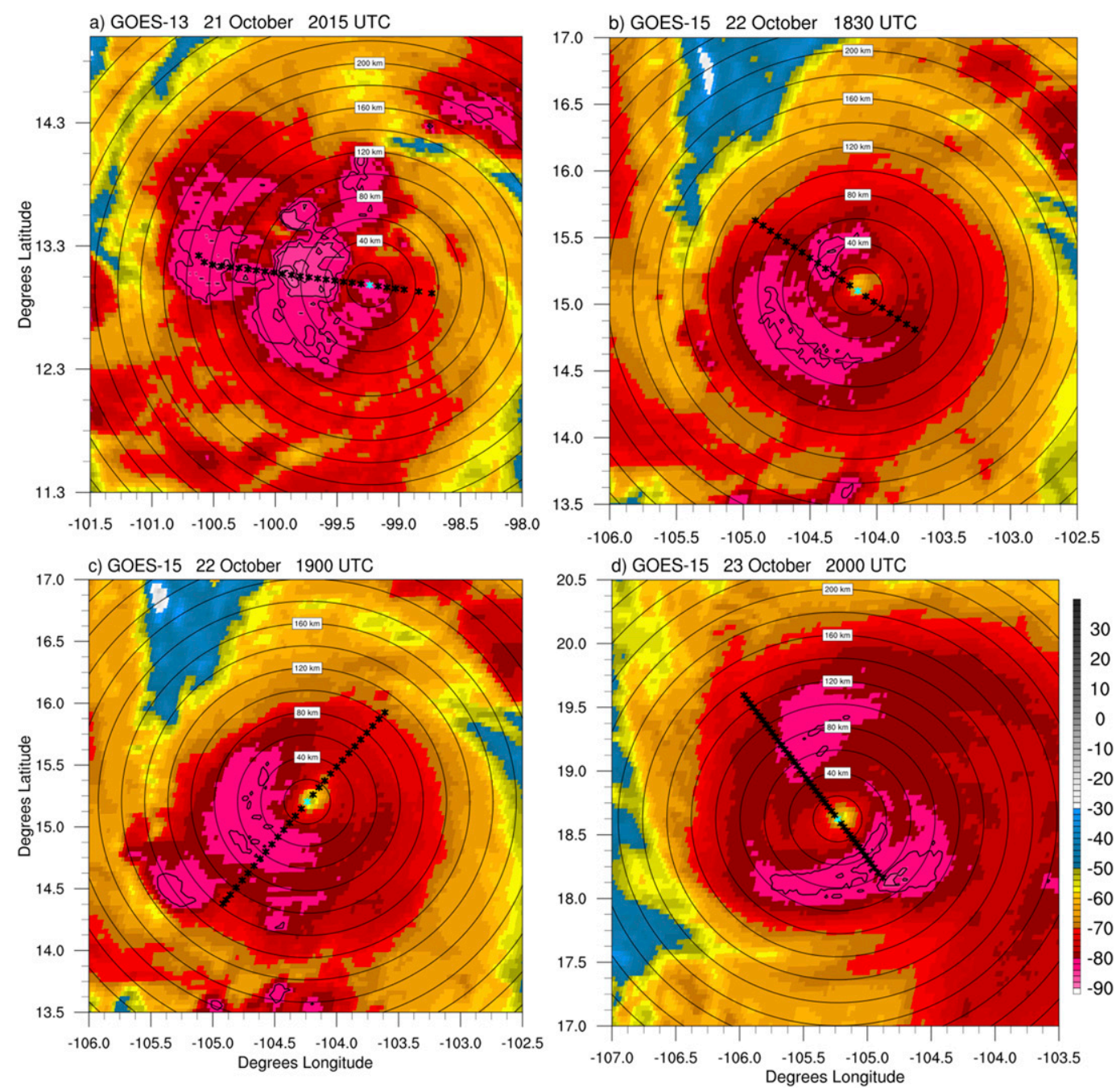

FIG. 1. Infrared brightness temperature $\left({ }^{\circ} \mathrm{C}\right.$ ) images of Tropical Storm Patricia at (a) 2015 UTC 21 Oct, and Hurricane Patricia at (b) 1830 UTC 22 Oct, (c) 1900 UTC 22 Oct, and (d) 2000 UTC 23 Oct 2015. Stars represent dropsonde deployment locations, with cyan stars marking the center location used for each cross section. Black contours delineate the coldest brightness temperatures, with a contour interval of $2^{\circ} \mathrm{C}$ starting at $-82^{\circ} \mathrm{C}$. The mean dropsonde spacing is (a) 7.9, (b) 7.8, (c) 8.0, and (d) $4.4 \mathrm{~km}$ for the four flight legs. Range rings are plotted every $20 \mathrm{~km}$.

Each sounding in the quality-controlled TCI dropsonde dataset (Bell et al. 2016) was interpolated to a $100-\mathrm{m}$ vertical grid following Molinari and Vollaro (2010). The static stability was analyzed using the Brunt-Väisälä frequency squared,

$$
N^{2}=\frac{g}{\theta} \frac{\Delta \theta}{\Delta z}
$$

where $\Delta z$ is $200 \mathrm{~m}$. The vertical temperature gradient, $\Delta T / \Delta z$, was also computed across 200-m layers using centered finite differences.

The evolution of $\theta$ anomalies will be used to aid the diagnosis of static stability changes. Although many previous papers have used the Jordan (1958) or Dunion
(2011) mean soundings to compute temperature anomalies, neither of these soundings are representative of the environment in which Patricia was embedded. For this reason, a mean state was defined using an average of 74 rawinsonde observations obtained from the University of Wyoming upper-air sounding archive (University of Wyoming 2016). These observations constituted all rawinsondes released from Manzanillo and Acapulco, Mexico, during October 2015. Each sounding was visually inspected for errors and three soundings from Manzanillo were removed from the average: 0000 UTC 6 October, 1200 UTC 11 October, and 1200 UTC 21 October. These soundings exhibited unrealistically large upper-tropospheric temperature departures relative to the previous and subsequent 
TABLE 1. Storm center positions from NOAA's Hurricane Research Division (HRD) zero wind center track for Hurricane Patricia, the nearest WB-57 dropsonde deployment location, and the distance $(\mathrm{km})$ between the two points.

\begin{tabular}{cccc}
\hline \hline Time and date & Storm center from HRD track & Location of nearest WB-57 dropsonde deployment & Separation distance \\
\hline 1957:00 UTC 21 Oct & $13.056^{\circ} \mathrm{N}, 99.244^{\circ} \mathrm{W}$ & $12.983^{\circ} \mathrm{N}, 99.235^{\circ} \mathrm{W}$ & $8.1 \mathrm{~km}$ \\
1823:15 UTC 22 Oct & $15.123^{\circ} \mathrm{N}, 104.149^{\circ} \mathrm{W}$ & $15.101^{\circ} \mathrm{N}, 104.142^{\circ} \mathrm{W}$ & $2.5 \mathrm{~km}$ \\
1906:00 UTC 22 Oct & $15.238^{\circ} \mathrm{N}, 104.247^{\circ} \mathrm{W}$ & $15.204^{\circ} \mathrm{N}, 104.237^{\circ} \mathrm{W}$ & $3.9 \mathrm{~km}$ \\
2001:30 UTC 23 Oct & $18.617^{\circ} \mathrm{N}, 105.199^{\circ} \mathrm{W}$ & $18.590^{\circ} \mathrm{N}, 105.207^{\circ} \mathrm{W}$ & $3.1 \mathrm{~km}$ \\
\hline
\end{tabular}

soundings. Their removal did not significantly alter the mean sounding: the maximum difference in the average temperatures computed with and without those soundings was $0.47^{\circ} \mathrm{C}$. A total of 58 of the 74 rawinsondes reported data up to at least the $19-\mathrm{km}$ level, facilitating the computation of $\theta$ anomalies well into the lower stratosphere.

For each cross section, the storm center location was determined using a wind center track produced by NOAA's Hurricane Research Division (available online at http://www.aoml.noaa.gov/hrd/Storm_pages/ patricia2015/patricia.trak). The WB-57 dropsonde deployment location nearest this storm center estimate in space and time was used to define the center (radius $=0$ ) for each cross section. The distance between the nearest dropsonde and the storm track never exceeded $8.1 \mathrm{~km}$ (Table 1). Storm-relative radial and tangential velocities were computed using the speed and direction of motion along this track.

\section{Results}

The center-crossing transects on 21,22, and 23 October 2015 are shown in Figs. 1a-d, overlaid on infrared brightness temperature images from GOES. Stars indicate dropsonde deployment locations and range rings are plotted every $20 \mathrm{~km}$. Brightness temperatures colder than $-80^{\circ} \mathrm{C}$ extended over a broad region of Patricia's circulation on 21 October (Fig. 1a, pink shading). Convection was asymmetric about the storm center, with the coldest brightness temperatures (colder than $-86^{\circ} \mathrm{C}$ ) confined to a region $60-80 \mathrm{~km}$ west of Patricia's center of circulation. By 22 October, Patricia had rapidly intensified to a category 3 hurricane (Fig. 2), with an eye beginning to clear in the infrared (Figs. 1b,c). This rapid intensification continued over the next $18 \mathrm{~h}$ until the storm's maximum sustained wind speed reached its peak of $185 \mathrm{kt}\left(1 \mathrm{kt}=0.5144 \mathrm{~m} \mathrm{~s}^{-1}\right)$ at 1200 UTC 23 October (Fig. 2; Kimberlain et al. 2016). TCI conducted its final flight into Patricia shortly thereafter, crossing over the eye around 2000 UTC (Fig. 1d) as the storm began to weaken.

The tropopause temperature, pressure, and $\theta$ observed along these four transects (Fig. 3) exhibit strong spatial and temporal variability. On 21 October, the tropopause temperature (Fig. 3a, blue line) was colder than $-80^{\circ} \mathrm{C}$ at all radii. The coldest tropopause temperature observed, $-84^{\circ} \mathrm{C}$, was located about $45 \mathrm{~km}$ west of the storm center, within a region of IR brightness temperatures between $-84^{\circ}$ and $-86^{\circ} \mathrm{C}$. These cold tropopause temperatures west of the storm center tended to be associated with lower tropopause pressure (Fig. 3b, blue line). On this day, tropopause $\theta$ (Fig. 3c, blue line) varied from $374 \mathrm{~K}$ east of the storm center to $385 \mathrm{~K}$ west of the storm center. By 22 October (green and orange lines), all three tropopause quantities had changed dramatically. The tropopause temperature increased everywhere, and at the storm center temperature rose from near $-83^{\circ} \mathrm{C}$ on 21 October to $-77^{\circ} \mathrm{C}$ in the first transect on 22 October (Fig. 3a, green line). During this same period, the tropopause pressure at the storm center decreased from 93 to $85 \mathrm{hPa}$. This combination of increasing temperature and decreasing pressure led to a

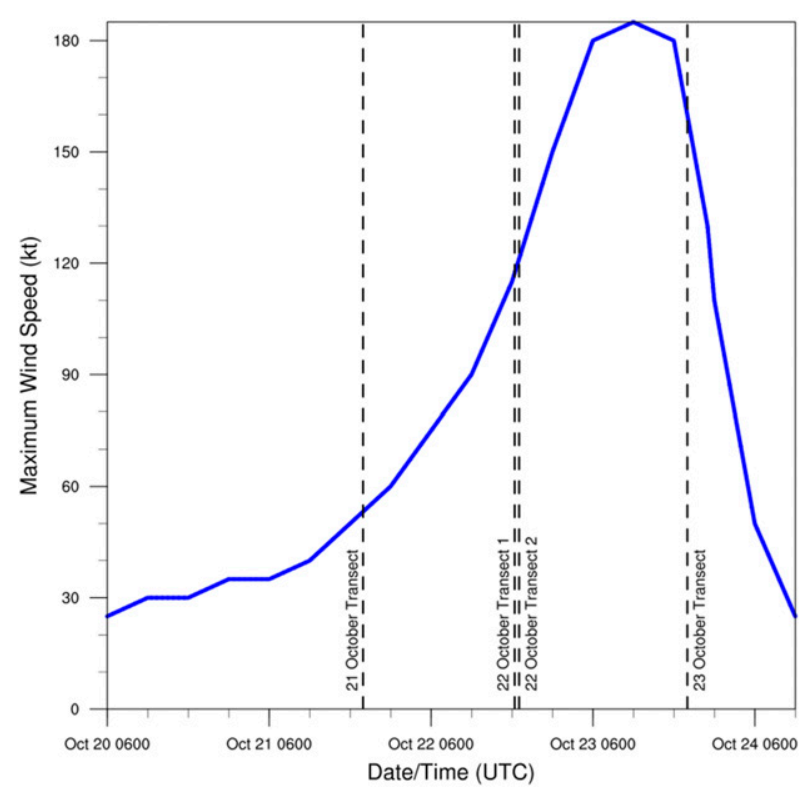

FIG. 2. The maximum wind speed (kt; blue line) throughout Patricia's lifetime recorded in the National Hurricane Center best track (Kimberlain et al. 2016). Vertical lines indicate the times at which the WB-57 passed over the storm center during the four transects shown in Fig. 1. 

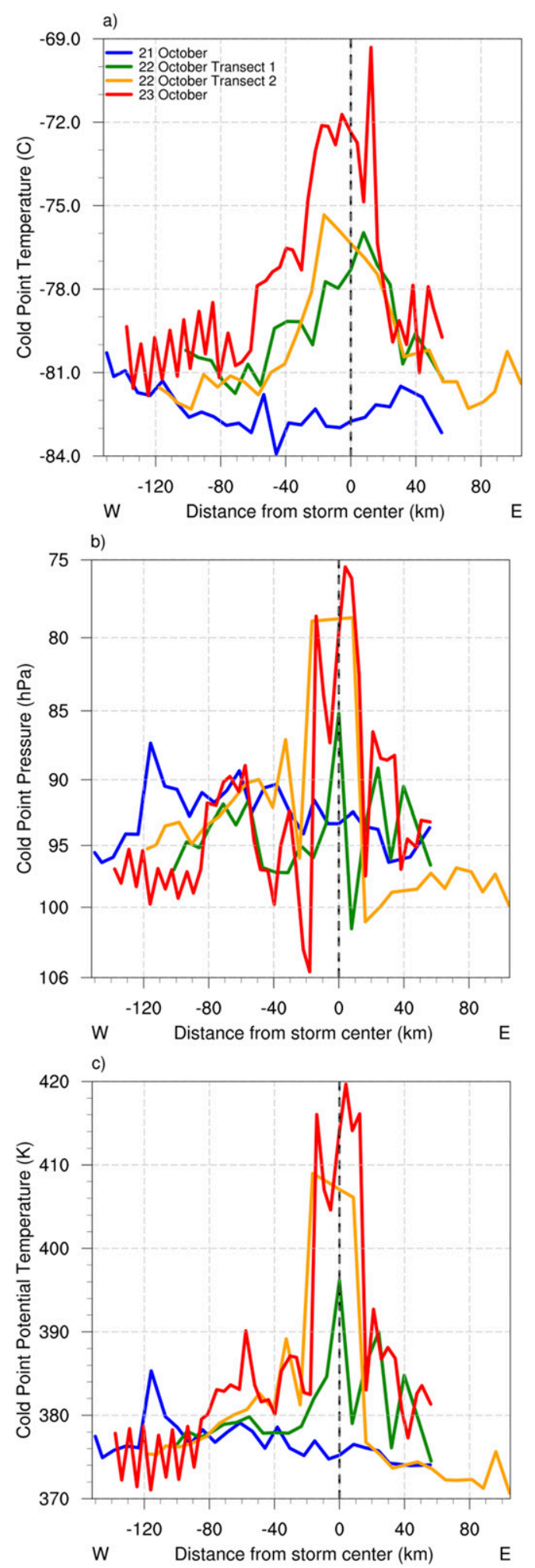

FIG. 3. (a) Temperature $\left({ }^{\circ} \mathrm{C}\right)$, (b) pressure $(\mathrm{hPa})$, and (c) potential temperature $(\mathrm{K})$ at the cold-point tropopause for flights through the center of Tropical Storm Patricia at 1957 UTC 21 Oct (blue), and Hurricane Patricia at 1823 UTC 22 Oct (green), 1906 $\theta$ increase of greater than $20 \mathrm{~K}$ at the tropopause. The dropsonde deployed nearest Patricia's center of circulation during the second transect (orange lines) was missing all data above $11.7 \mathrm{~km}$. However, another dropsonde deployed on the northeast edge of the eye observed a tropopause pressure and temperature of $79 \mathrm{hPa}$ and $-77^{\circ} \mathrm{C}$, respectively. This corresponded to a tropopause $\theta$ of $406 \mathrm{~K}$, which was $31 \mathrm{~K}$ higher than that observed at the storm center less than $24 \mathrm{~h}$ prior. These trends continued into 23 October (red lines), by which time the tropopause temperature at the storm center had increased to $-72^{\circ} \mathrm{C}$ and the pressure approached $75 \mathrm{hPa}$ - the highest available data point-in two dropsondes deployed near the southeast edge of the eyewall.

Cross sections of $\Delta T / \Delta z\left[\mathrm{~K}(100 \mathrm{~m})^{-1}\right.$; Figs. $\left.4 \mathrm{a}-\mathrm{d}\right]$ and $N^{2}\left(10^{-4} \mathrm{~s}^{-2}\right.$; Figs. $\left.4 \mathrm{e}-\mathrm{h}\right)$ reveal dramatic changes in the static stability structure near the tropopause during Patricia's RI. On 21 October (Fig. 4a), the cold-point tropopause was located between 16.9 and $17.4 \mathrm{~km}$ - a few hundred meters higher than the annual-mean tropopause height in the tropical east Pacific (see Seidel et al. 2001, their Fig. 4a). A strong TIL (inversions represented by red shading) existed immediately above the tropopause, with temperature increasing upward by $2 \mathrm{~K}(100 \mathrm{~m})^{-1}$ over a broad region of the circulation. This inversion was similar in magnitude to those observed by Gentry (1967) and Waco (1970) in Hurricanes Isbell (1964) and Beulah (1967), and manifested as a 500-m-thick ribbon of $N^{2}$ greater than $10^{-3} \mathrm{~s}^{-2}$ (Fig. 4e). This inversion was strongest in the vicinity of the coldest cloud tops (Fig. 1a), reaching magnitudes greater than $4.5 \mathrm{~K}$ $(100 \mathrm{~m})^{-1}$ at four locations west of the storm center. Three of these maxima were accompanied by $100-\mathrm{m}$ upward spikes in tropopause height and stronger lapse rates just below the tropopause than were observed outside of the coldest cloud tops. The dropsondes with the strongest inversions-dropsondes 13 and 15-were deployed within the region of coldest IR brightness temperature $40-80 \mathrm{~km}$ west of the center. This suggests some connection between the presence of localized deep convection and a strong TIL, which will be discussed in section 4.

By 1823 UTC 22 October (Fig. 4b), the TIL had thinned and weakened considerably, particularly near the storm center. Between 10- and 20-km radius on each

\footnotetext{
$\longleftarrow$

UTC 22 Oct (orange), and 2001 UTC 23 Oct (red) 2015. The vertical dashed lines represent the storm center. Compass directions are indicated by letters at each end of the cross section.
} 

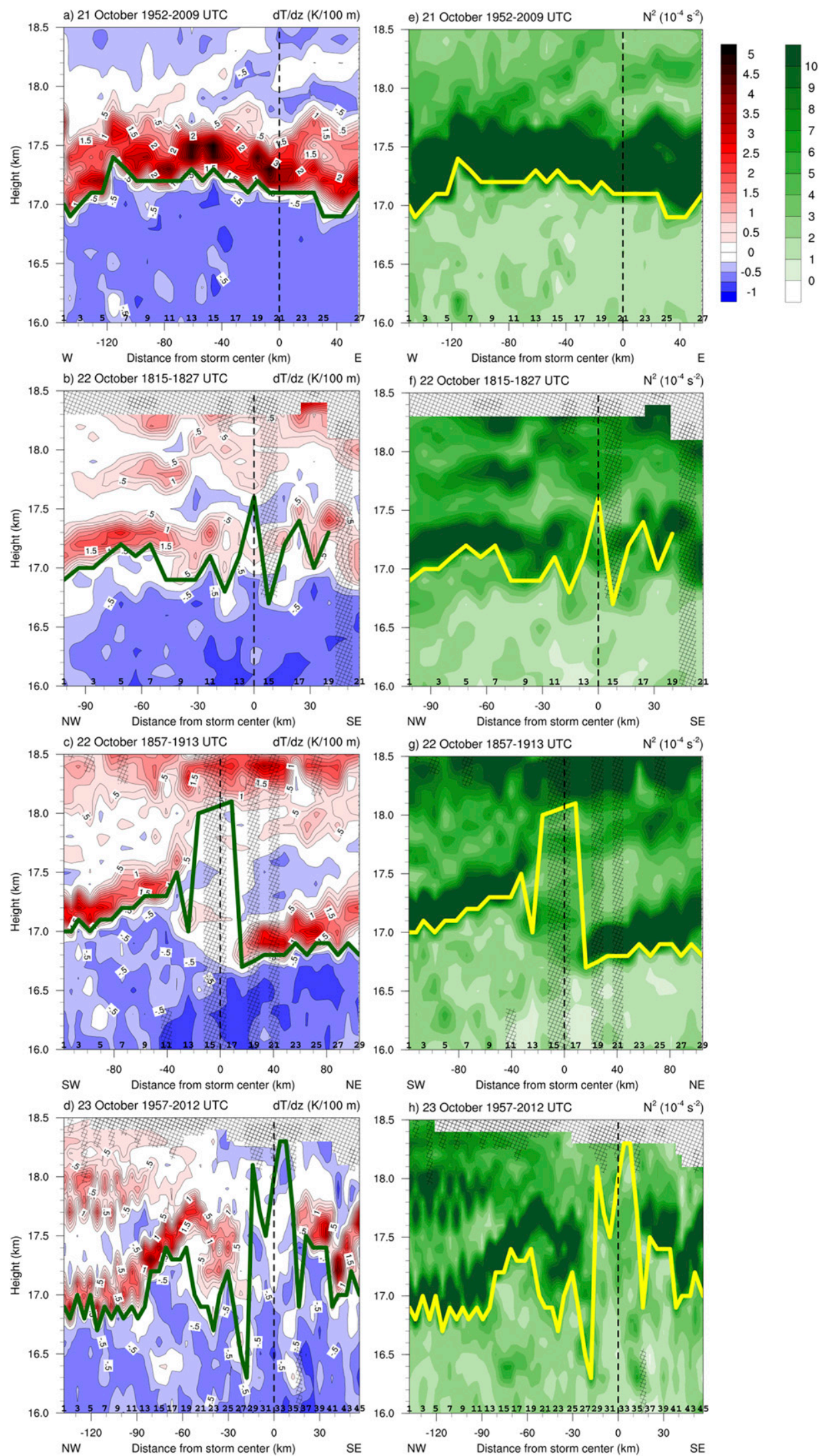
side, near the outer edge of the eye, the temperature profile became approximately isothermal above about $16.6 \mathrm{~km}$. These isothermal layers corresponded to slightly larger static stability in the $16.5-17-\mathrm{km}$ layer than was observed on the previous day, but smaller static stability above $17 \mathrm{~km}$ (cf. Figs. 4e,f). The decay of the TIL during this period allowed the tropopause height to increase at and southeast of the storm center, as can be seen by comparing the blue and green lines in Fig. $3 b$. Northwest of the storm center, meanwhile, the static stability below $17 \mathrm{~km}$ increased, and the tropopause height decreased. Some remnants of the TIL remained, with a small region marked by a $2 \mathrm{~K}(100 \mathrm{~m})^{-1}$ temperature inversion $70-80 \mathrm{~km}$ northwest of the storm center. Localized areas of large static stability also were present in the $17.5-18.5-\mathrm{km}$ layer.

Forty minutes later, a southwest-northeast transect observed a similar structure in the southwestern quadrant of the storm, with a temperature inversion persisting outside of the $40-\mathrm{km}$ radius (Fig. 4c). In the eye region, however, the TIL had eroded further and the tropopause height increased to 18 and $18.1 \mathrm{~km}$ southwest and northeast of the center, respectively. Although the dropsonde deployed nearest the storm center and the dropsonde deployed just to its southwest are missing data in the tropopause layer, two dropsondes near the edge of the eye-dropsondes number 14 and 17observed a nearly isothermal layer extending from $16.7 \mathrm{~km}$ upward to $18 \mathrm{~km}$. The transition from an inversion layer on 21 October to an isothermal layer on 22 October was associated with decreasing static stability in the eye region during this period (cf. Figs. 4e,g) and an increase in tropopause height. Southwest of the eye, a persistent TIL limited the tropopause height to the layer between 17 and $17.5 \mathrm{~km}$, and northeast of the eye, between 16.7 and $16.9 \mathrm{~km}$ (Fig. 4c). The asymmetry in tropopause height is coincident with a convective asymmetry characterized by coldest brightness temperatures southwest of the storm center and warmest brightness temperatures northeast of the storm center (Fig. 1c).
On 23 October (Figs. 4d,h), the tropopause reached $18.3 \mathrm{~km}$ - the maximum level of available data - in two soundings through Patricia's eye (dropsondes 33 and 34). This represents a further increase in tropopause height over the eye between 22 and 23 October, and was associated with decreasing static stability during that period within the $20-\mathrm{km}$ radius (cf. Figs. $3 \mathrm{~g}, \mathrm{~h}$ ). In contrast, no sounding outside of the $20-\mathrm{km}$ radius observed a tropopause higher than $17.5 \mathrm{~km}$. These regions saw a restrengthening of the TIL, with a large number of dropsondes once again observing temperature inversions of magnitude greater than $2 \mathrm{~K}(100 \mathrm{~m})^{-1}$, especially above the eyewall regions near $70 \mathrm{~km}$ northwest and $30 \mathrm{~km}$ southeast of the storm center. These regions also were marked by local maxima in tropopause height. Near 10-20-km radii on each side of the storm center, like the previous day, there was a layer of nearly zero $\Delta T / \Delta z$, extending down to the $16.2-\mathrm{km}$ level, which was deeper into the troposphere than on the previous day. It is unclear what caused these quasi-isothermal layers on the outer edge of the eye, but their existence complicates the definition of the tropopause. For example, the cold-point tropopause height in dropsonde number 28 was $16.3 \mathrm{~km}$, where the temperature reached its minimum of $-72.12^{\circ} \mathrm{C}$. The same dropsonde, however, observed a temperature of $-72.07^{\circ} \mathrm{C}$ at $17.8 \mathrm{~km}$. The difference between these two temperatures was well within the margin of error of the dropsonde temperature sensor $\left(0.5^{\circ} \mathrm{C}\right.$; Bell et al. 2016). Thus, the coldpoint tropopause might have been much higher at these locations and we do not attribute any significance to the sharp, localized drops in tropopause height on each side of the eye. In contrast, the presence of an elevated tropopause over the eye in multiple soundings on 22 and 23 October, together with the systematic increase in tropopause height throughout the observation period, lends confidence that the elevated tropopause over the eye is a real signal.

Cross sections of $\theta$ are shown in Figs. 5a-d and $\theta$ anomalies in Figs. 5e-h. On 21 October, a broad region of Patricia's inner core exhibited $\theta$ anomalies colder

FIG. 4. (left) Vertical cross sections of $\Delta T / \Delta z\left[\mathrm{~K}(100 \mathrm{~m})^{-1}\right.$; filled contours] and the cold-point tropopause height (green lines) along the transects shown in Fig. 1 on (a) 21; (b),(c) 22; and (d) 23 Oct 2015. Numbers along the bottom of each cross section represent the dropsonde deployment locations shown in Fig. 1 (only odd-numbered dropsondes are labeled here), with number 1 corresponding to the westernmost dropsonde. Compass directions are indicated by letters at each end of the cross sections. Dashed vertical lines mark the storm center and hatching indicates regions of missing values, where linear interpolation is performed in the radial direction. (right) Vertical cross sections of Brunt-Väisälä frequency squared $\left(10^{-4} \mathrm{~s}^{-2}\right.$; filled contours) and cold-point tropopause height (yellow lines) on (e) 21; (f),(g) 22; and (h) 23 Oct 2015. 
than $-4 \mathrm{~K}$ at and just below the tropopause (Fig. 5e). Immediately above this anomalous cold layer existed a layer with warm anomalies greater than $8 \mathrm{~K}$. This anomalous warm layer, combined with the anomalous cold layer at and below the tropopause, helped to produce the particularly well-defined TIL observed on 21 October (Fig. 4a). As Patricia's RI commenced, an upper-tropospheric warm core began to develop within the $30-\mathrm{km}$ radius. For example, the maximum $\theta$ at the $16-\mathrm{km}$ level increased from approximately $368 \mathrm{~K}$ on 21 October (Fig. 5a) to $378 \mathrm{~K}$ on 22 October (Fig. 5c). Meanwhile, the horizontally extended cold anomaly at and just beneath the tropopause weakened considerably, as did the warm anomaly in the lower stratosphere. Just above the tropopause to the northeast of the storm center, however, a warm anomaly of up to $8 \mathrm{~K}$ remained (Fig. $5 \mathrm{~g}$ ), along with a cold anomaly of up to $4 \mathrm{~K}$ immediately surrounding the tropopause. Later in the RI period (22-23 October), Patricia's warm core developed more rapidly, with the strongest warming confined to within $20 \mathrm{~km}$ of the storm center. By 23 October, uppertropospheric $\theta$ within the eye exceeded $400 \mathrm{~K}$-a value previously found only in the lower stratosphere. Oscillations in $\theta$, possibly inertia-gravity waves, are evident to the northwest of the eye just radially outside of the secondary eyewall (Fig. 5d), extending from $60 \mathrm{~km}$ to at least $130 \mathrm{~km}$ northwest of the storm center. These waves affected the static stability all the way up to $18 \mathrm{~km}$ (Fig. 4h), caused 100-200-m fluctuations in the tropopause height, and were associated with oscillations in radial and tangential velocity (not shown). A detailed analysis of these waves is outside of the scope of this paper, but to our knowledge this may be the first time that inertia-gravity waves have been resolved by dropsondes in a hurricane.

Changes in $\theta$ over $24 \mathrm{~h}$ (Fig. 6) highlight two distinct periods of $\theta$ evolution during Patricia's RI. Figure 6a shows the change in $\theta$ between 21 and 22 October (Fig. $5 \mathrm{f}$ minus Fig. 5e) and Fig. $6 \mathrm{~b}$ the $\theta$ change between 22 and 23 October (Fig. 5h minus Fig. 5f). ${ }^{1}$ The differences are scaled to $24 \mathrm{~h}$ by multiplying by $24 / \Delta t$, where $\Delta t$ is the time (in hours) separating the center crossings of the two transects. During the early part of Patricia's RI (Fig. 6a), $\theta$ decreased dramatically above the $17.5-\mathrm{km}$ level, with cooling greater than $10 \mathrm{~K}$ observed at nearly all radii over a $24-\mathrm{h}$ period. A radially extensive region

\footnotetext{
${ }^{1}$ We have chosen to use only the first transect on 22 October (Fig. 1b) because it sampled the same quadrants as the centercrossing transects on 21 and 23 October; difference fields using the second, southwest-northeast, transect on 22 October (Fig. 1c) are qualitatively similar (not shown).
}

of warming existed just a few hundred meters below this strong cooling, with $\theta$ increases of at least $4 \mathrm{~K}$ observed at nearly all radii. These $\theta$ increases maximized in the 17.0-17.4-km layer-the layer in which the tropopause was located throughout much of the cross section (see Figs. 4a,b). Later in the RI period (Fig. 6b), $\theta$ increased over almost the entire domain, including in the lower stratosphere up to at least $18.4 \mathrm{~km}$. These increases no longer maximized in a thin, horizontally extended layer near the tropopause; rather, the largest $\theta$ changes were confined to a region within $30 \mathrm{~km}$ of the storm center. Maximum $\theta$ tendencies flanked the storm center on each side, consistent with the "warm ring" noted by Schubert et al. (2007) and Stern and Zhang (2013). Within the eye region (radius $<20 \mathrm{~km}$ ), the magnitude of the positive $\theta$ tendencies generally decreased with height above $17.2 \mathrm{~km}$, which indicates a destabilization of the layer above $17.2 \mathrm{~km}$ during this period, as was shown in Fig. 4.

The two distinct modes of $\theta$ variability seen in Fig. 6 suggest that the dominant processes governing $\theta$ evolution in the upper troposphere and lower stratosphere changed throughout Patricia's RI. The change in the vertical profiles of $\theta$ at the storm center during this time is illustrated in Fig. 7. Between 21 (blue line) and 22 October (orange line), tropospheric $\theta$ increased almost uniformly in the layer between 16 and $17.1 \mathrm{~km}$, consistent with the increasing inner-core $\theta$ that is expected in an intensifying TC. In contrast, the layer above $17.1 \mathrm{~km}$ was characterized by increasing $\theta$ below $17.3 \mathrm{~km}$ and decreasing $\theta$ above. Inset on the bottom right of Fig. 7 is a schematic diagram of turbulent mixing across a highly stable layer. Mixing will tend to increase $\theta$ below the stable layer and decrease $\theta$ above, with the maximum tendencies occurring immediately below and above the initial stability maximum. The 24-h $\theta$ change during the 21-22 October period (Fig. 6a) shows precisely this structure-with $\theta$ tendencies maximized in a shallow, horizontally extended layer immediately surrounding the tropopause-an indication that turbulent mixing might have played a role in weakening the TIL early in the period. This hypothesis is supported by previous work that observed layers conducive to turbulence in the upper levels of hurricanes (Molinari et al. 2014; Duran and Molinari 2016) and radar observations of upper-tropospheric turbulence in TCs (Das et al. 2008).

Observations of IR brightness temperature during this period suggest that overshooting convection might have acted as an agent of this mixing, consistent with previous observations and numerical simulations (e.g., Danielsen 1993; Salby et al. 2003). The time evolution of overshooting convection throughout Patricia's lifetime is expressed in Fig. 8 as a radius-time diagram. This plot 

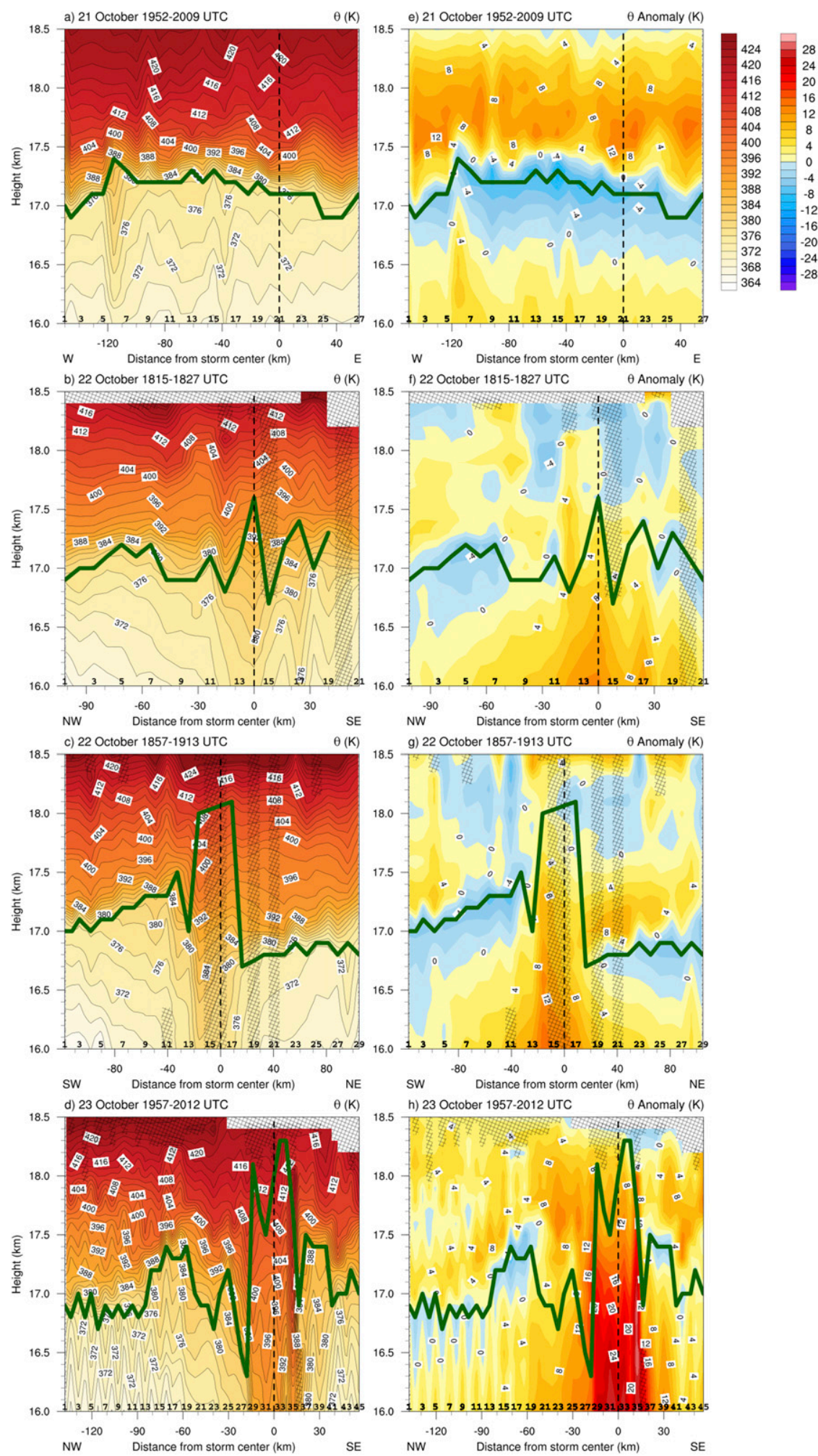

FIG. 5. (left) Vertical cross sections of potential temperature $\left({ }^{\circ} \mathrm{C}\right.$; filled contours) and the cold-point tropopause height (green lines) along the transects shown in Fig. 1 on (a) 21; (b), (c) 22; and (d) 23 Oct 2015. Dropsonde locations, compass directions, and hatching as in Fig. 4. (right) Vertical cross sections of the potential temperature anomaly $\left({ }^{\circ} \mathrm{C}\right)$ on (e) 21 ; (f), (g) 22; and (h) 23 Oct 2015. 

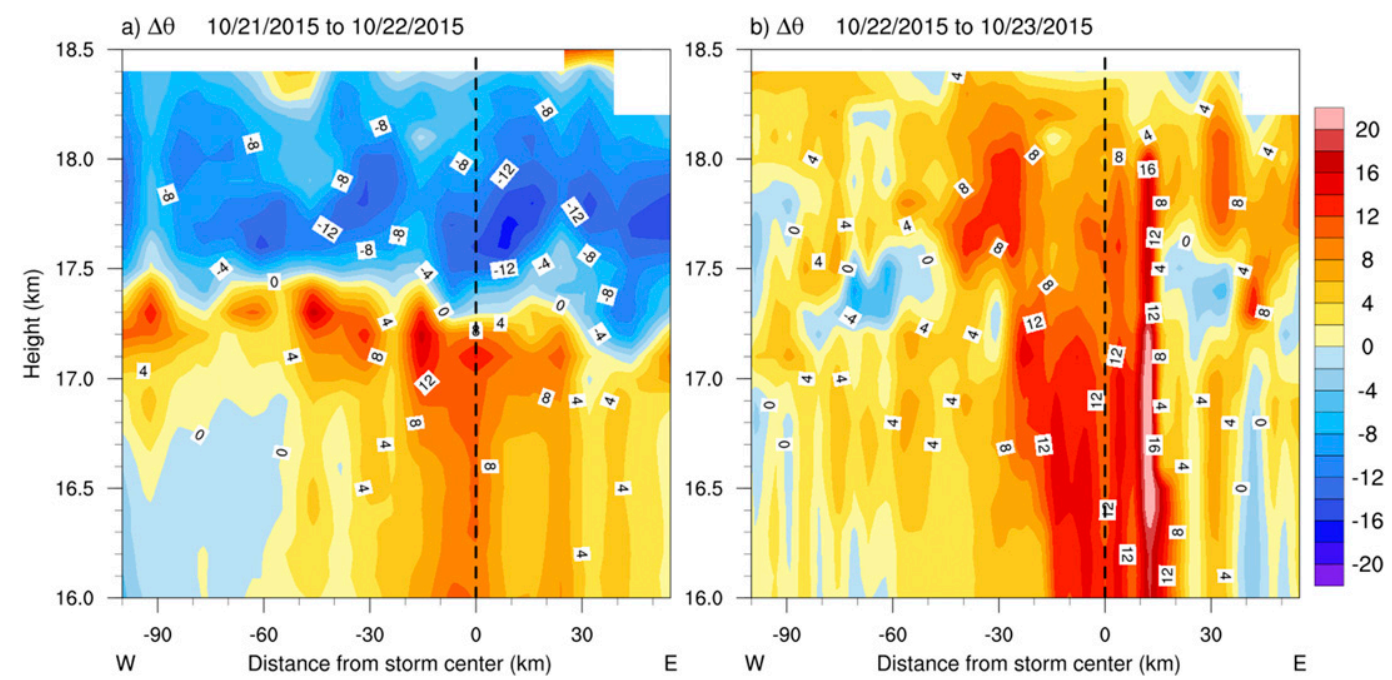

FIG. 6. Vertical cross sections of the potential temperature change $\left(\mathrm{K} \mathrm{day}^{-1}\right)$ from (a) 21 to 22 Oct and (b) 22 to 23 Oct. These panels extend from the $100-\mathrm{km}$ radius in Patricia's western semicircle to $55 \mathrm{~km}$ in the eastern semicircle. The times separating the transects $(\Delta t)$ were $22.45 \mathrm{~h}(21-22 \mathrm{Oct})$ and $25.63 \mathrm{~h}(22-23 \mathrm{Oct})$. To ease comparison between the two time periods, the potential temperature changes are scaled to $24 \mathrm{~h}$ by multiplying by $(24 / \Delta t)$.

is created by counting the number of IR pixels colder than $-80^{\circ} \mathrm{C}$ in a 5 -km-wide annulus and dividing by the total number of pixels in that annulus. This is performed out to the $300-\mathrm{km}$ radius using GOES-13 imagery every 30 min throughout Patricia's lifetime, and the percentages are plotted at the midpoint of each annulus. Since the cold-point temperature in Patricia's eyewall region remained near $-80^{\circ} \mathrm{C}$ throughout most of its RI (Fig. 3a), this temperature was chosen as the cutoff for overshooting convection. As in Ebert and Holland (1992), any regions characterized by brightness temperature colder than the tropopause are assumed to contain overshooting convective towers. Prior to the first WB-57 center crossing on 21 October, very little overshooting convection was observed; however, cloud tops colder than $-80^{\circ} \mathrm{C}$ began to cover a larger area right around the time of the first transect. These cold cloud tops were not necessarily overshooting, however, since the cold-point temperature observed by dropsondes at this time was in the $-81^{\circ}$ to $-84^{\circ} \mathrm{C}$ range (Fig. 3a). To determine the full distribution of the coldest brightness temperatures, a contoured frequency by time diagram (CFTD) is shown in Fig. 9. This plot is analogous to the contoured frequency by altitude diagram (CFAD) described in detail by Yuter and Houze (1995), except with time as the ordinate rather than altitude. Each point on the plot represents the percent of IR pixels within the $300-\mathrm{km}$ radius that have the brightness temperature indicated by the abscissa, at the time indicated by the ordinate. At the time of the 21 October transect, very few IR pixels colder than $-81^{\circ} \mathrm{C}$ were observed, which indicates that convection overshooting the tropopause was not very widespread at this time. Soon after the 21 October transect, however, cloud tops colder than $-80^{\circ} \mathrm{C}$ became much more common within the $300-\mathrm{km}$ radius (Fig. 8). This time period leading up to the transects on 22 October also saw a dramatic increase in the coverage of the coldest cloud tops (Fig. 9), with the distributions of IR brightness temperature maximizing near $-84^{\circ} \mathrm{C}$ throughout much of the period. Between 0000 and 0600 UTC 22 October, IR pixels as cold as $-90^{\circ} \mathrm{C}$ were observed, which is $6^{\circ} \mathrm{C}$ colder than the coldest temperature observed by dropsondes during the 21 October transect (Fig. 3a). These observations point to a considerable increase in the extent of overshooting convection between the flights on 21 and 22 October. It is well known that deep, overshooting convection can affect the $\theta$ stratification near the tropopause through not only mixing, but also upper-tropospheric latent heating (Salby and Callaghan 2004) and cooling by adiabatic lofting (Sherwood et al. 2003) and detrainment (Salby et al. 2003). We hypothesize that the localized upward bulges observed in the regions of coldest IR brightness temperature-and their corresponding cold anomaliesare the result of adiabatic lofting by individual overshooting convective towers. These convective-scale processes strongly cool a layer at and below the tropopause, which leads to an increase in the vertical gradient of $\theta$ just above the tropopause, thus increasing $N^{2}$ locally and strengthening the TIL. In addition, we hypothesize that on the mesoscale, cold air detraining from these overshooting convective towers acted to cool the lower stratosphere. This lower-stratospheric cooling, combined with turbulent mixing across the tropopause 


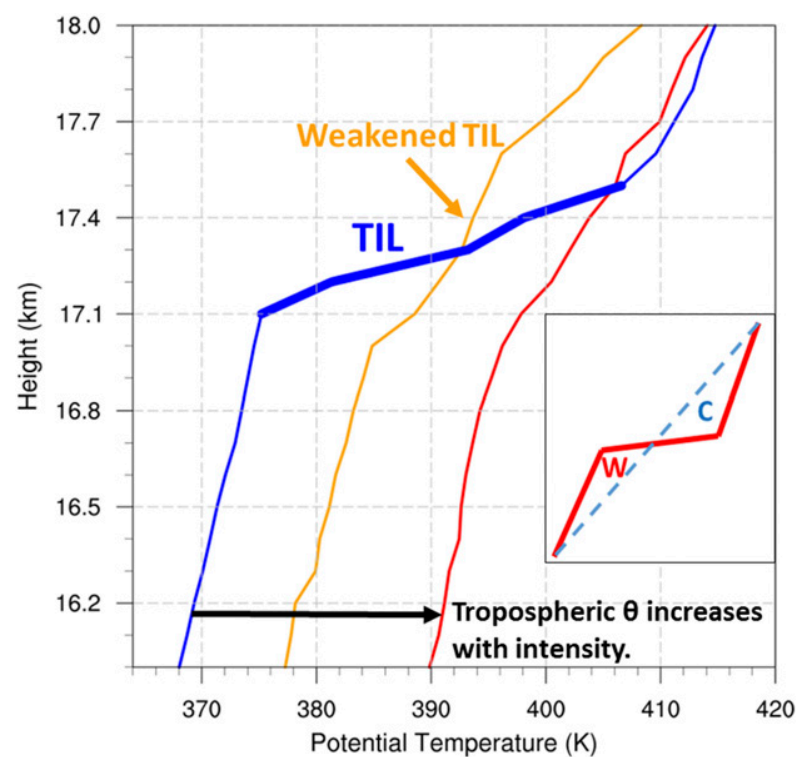

FIG. 7. Vertical profiles of potential temperature (K) between 16- and 18-km height for the soundings at Patricia's storm center on 21 Oct (blue), 22 Oct (orange), and 23 Oct 2015 (red). The bolded segment of the blue line denotes the TIL on 21 Oct. (inset) A simplified schematic of mixing across a strongly stable layer, with the solid red line indicating the initial potential temperature profile and the dashed blue line representing the profile after a period of mixing; "W" and " $\mathrm{C}$ " represent regions of warming and cooling, respectively, after mixing.

and upper-tropospheric latent heating, acted to decrease the vertical gradient of $\theta$ across the tropopause, thus decreasing $N^{2}$ and causing the observed weakening of the TIL during this period (Fig. 4).

Later in the RI period (22-23 October), the lower stratosphere ceased cooling and $\theta$ tendencies no longer maximized in the immediate vicinity of the tropopause. Potential temperature changes over this time period were almost exclusively positive in the inner core (Fig. 6b), and the vertical gradient of $\theta$ at the storm center remained nearly constant in the $16-18.5$-km layer (Fig. 7). Throughout much of this period, nearly $100 \%$ of the $50-100-\mathrm{km}$ radial band contained brightness temperatures colder than $-80^{\circ} \mathrm{C}$ (Fig. 8). The extremely cold cloud tops that dominated the previous day, however, were no longer observed; rather, the brightness temperature distributions peaked near $-80^{\circ} \mathrm{C}$ for most of the period, and rapidly warmed leading up to the center crossing on 23 October (Fig. 9). These observations, in union with the observed cold-point temperature hovering around $-80^{\circ} \mathrm{C}$ in the $50-100-\mathrm{km}$ radial band on 22 and 23 October (Fig. 3a), suggest that convection did not overshoot as far into the stratosphere during this period than it did during the previous $24 \mathrm{~h}$. An expected consequence of this decreased convective

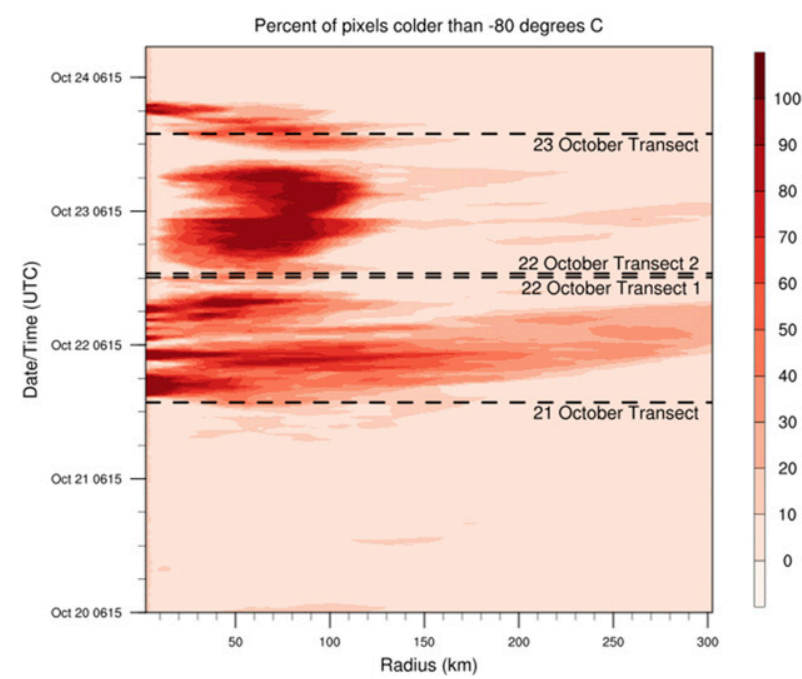

FIG. 8. Radius-time plot of the percent of infrared brightness temperature pixels colder than $-80^{\circ} \mathrm{C}$. The plot is constructed by counting the number of pixels colder than $-80^{\circ} \mathrm{C}$ in a $5-\mathrm{km}$-wide radial bin, dividing by the total number of pixels in that bin, and multiplying by 100 . This is performed every $5 \mathrm{~km}$, extending from the storm center out to $300-\mathrm{km}$ radius, for each GOES-13 image collected during Patricia's lifetime (images are available every $30 \mathrm{~min}$ ). Dashed black lines mark the times at which the WB-57 aircraft crossed over the storm center.

overshooting is a decrease in the degree and depth of lower-stratospheric cooling (e.g., Kuang and Bretherton 2004), which might explain why the lower stratosphere ceased cooling between 22 and 23 October. Another possible consequence of a decrease in overshooting convection is a decrease in the intensity of turbulent mixing across the tropopause. Even if the intensity of turbulence remained constant, however, the smaller vertical $\theta$ gradient observed on 22 and 23 October (Fig. 7) would yield a smaller $\theta$ tendency forced by mixing. In summary, it appears that the effects of mixing and lower-stratospheric convective detrainment became less important later in Patricia's RI, and subsidence warming was probably the leading cause of the positive $\theta$ tendencies observed in the eye. These positive tendencies, decreasing upward, contributed to a further destabilization of the tropopause layer and the highly localized increase in tropopause height over the eye.

\section{Discussion}

The four high-density dropsonde transects conducted through the center of Hurricane Patricia constitute the highest-resolution observations of tropopause evolution observed in a TC to date. These observations revealed dramatic tropopause variability during Patricia's RI, which can be split into two distinct periods: early RI and late RI. 


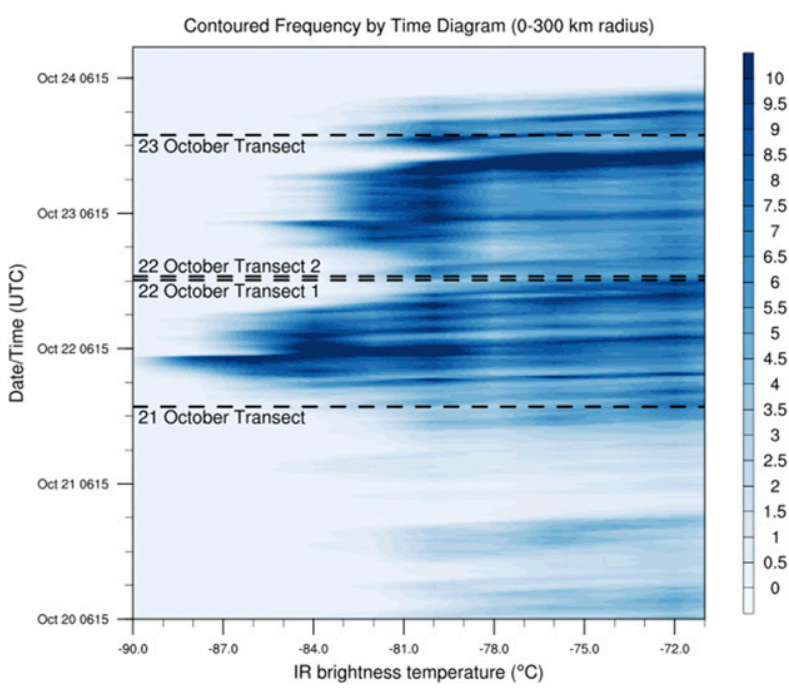

FIG. 9. Contoured frequency by time diagram of infrared (IR) brightness temperature $\left({ }^{\circ} \mathrm{C}\right)$ for all IR pixels within $300 \mathrm{~km}$ of the storm center observed by GOES-13 throughout Patricia's lifetime. The plot is constructed by sampling the full distribution of IR brightness temperature within $300 \mathrm{~km}$ of the storm center and determining the percentage of pixels that fall into each IR brightness temperature bin (using 2-K-wide bins). Dashed black lines mark the times at which the WB-57 aircraft crossed over the storm center.

\section{a. Early RI}

The early part of Patricia's RI (21-22 October) was characterized by widespread overshooting convection within $300 \mathrm{~km}$ of the storm center (Figs. 8 and 9). We hypothesize that this convection generated turbulent mixing across the tropopause, which acted to warm the upper troposphere and cool the lower stratosphere. This is supported by Robinson and Sherwood's (2006) cloud-resolving simulations of deep tropical convection, which generated convective towers that penetrated to a height $1.5 \mathrm{~km}$ above the cold-point tropopause. Turbulence generated by this overshooting convection mixed air across the tropopause, importing parcels of stratospheric origin down to as far as $2-3 \mathrm{~km}$ below the tropopause (their Fig. 5). This mixing acted to warm the upper troposphere and cool the lower stratosphere (their Fig. 7), with the lower-stratospheric cooling maximized just a few hundred meters above the tropopause. We also hypothesize that convective detrainment acted to warm the upper troposphere and cool the lower stratosphere, consistent with Salby et al. (2003), who observed that convective regions are characterized by negative $\theta$ anomalies extending up to the 46-hPa level (their Fig. 2). They attributed this anomalously cold lower stratosphere to detrainment from overshooting convective towers and irreversible mixing with environmental air.
Given these observations, we hypothesize that the $\theta$ evolution - and thus the static stability evolution-near the tropopause during this period was dominated by the effects of overshooting convection.

\section{b. Late RI}

The latter period of Patricia's RI (22-23 October) was characterized by less overshooting convection and increasing $\theta$ throughout almost the entire inner-core tropopause region. The strongest $\theta$ increases were confined to within $20 \mathrm{~km}$ of the storm center, consistent with the development of an upper-tropospheric warm core within Patricia's eye through subsidence warming (Fig. 6b).

Guimond et al. (2010) and Chen and Zhang (2013) attributed upper-level warm core formation to descent along the flanks of intense, deep convective towers. This convectively induced descent can facilitate the intrusion of stratospheric air into the upper troposphere, as described by Zhang and Chen (2012) and Ohno and Satoh (2015). Elevated ozone concentrations observed by aircraft in the eye of Hurricane Ginny (Penn 1965) and by land-based stations during the passage of tropical cyclones (Das et al. 2016) provide evidence for this stratospheric intrusion.

A number of modeling studies (Zhang and Chen 2012; Ohno and Satoh 2015; Kieu et al. 2016) note the development of a lower-stratospheric inflow layer connected to descent in the eye. Observations of radial velocity in Hurricane Patricia on 22 October (Figs. $10 \mathrm{a}, \mathrm{b})$ corroborate the existence of this inflow layer. These observations are also consistent with a neartropopause inflow layer observed by HS3 dropsondes in three different TCs (Komaromi and Doyle 2017). At the same time, Patricia's cyclonic circulation penetrated into the lower stratosphere in a few places (Figs. 6b,c), particularly near the eye. This is consistent with the model experiments of Ohno and Satoh (2015), in which an upper-level warm core developed while the cyclonic circulation grew into the lower stratosphere. The authors hypothesized that this upward growth of the circulation facilitated strong upper-tropospheric warming by concentrating downdrafts in a region of large static stability. The simulations of Stern and Zhang (2013) likewise developed a warm core near the tropopause, where static stability began to increase from its minimum in the upper troposphere. Our results are consistent with these interpretations. A weaker $\theta$ anomaly maximum also was present in the midlevels, where the static stability reached a secondary maximum (not shown). This stable stratification is a necessary ingredient for adiabatic subsidence to warm the eye. Regardless of the forcing mechanisms, the 

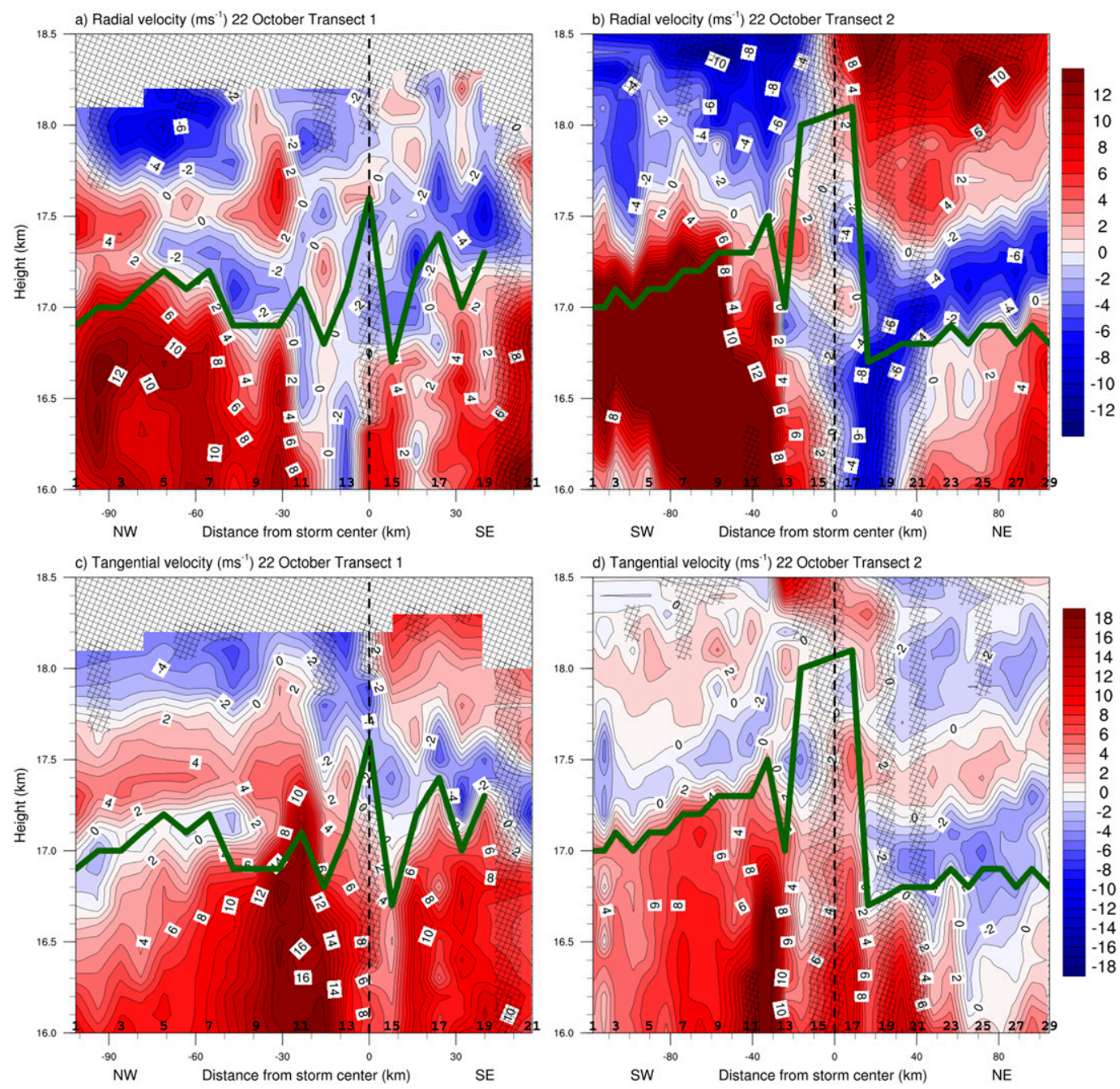

FIG. 10. Vertical cross sections of (a),(b) storm-relative radial and (c),(d) tangential velocity ( $\mathrm{m} \mathrm{s}^{-1}$ ) and the coldpoint tropopause height (green lines) in Hurricane Patricia for the two center-crossing transects on 22 Oct 2015. Dropsonde locations, compass directions, and vertical hatching as in Fig. 4.

strong upper-tropospheric warming between 22 and 23 October was enough to completely eliminate the TIL within the eye, allowing the tropopause height and temperature to increase dramatically.

\section{c. Characteristics common to early and late RI}

At every stage of Patricia's RI, the coldest IR brightness temperatures were associated with a higher and colder tropopause. This is consistent with a number of previous papers (e.g., Sherwood et al. 2003; Salby et al. 2003; Robinson and Sherwood 2006) that describe an elevation and cooling of the tropopause within convective regions as a response to adiabatic lofting and turbulent mixing. These papers demonstrated that the cooling by lofting and mixing tended to maximize just above the cold-point tropopause, which acted to both elevate and cool the tropopause within regions of intense convection. This shallow layer of cooling acted to increase the static stability just above the tropopause, which might account for the maintenance of the TIL over the eyewall regions throughout RI.

Notwithstanding regions of localized convective cooling, Patricia's inner-core tropopause consistently warmed with time throughout its RI (Fig. 3a). This is consistent with Komaromi and Doyle (2017), whose HS3 dropsonde analyses depicted a tropopause that was both higher and warmer over the inner core of intense TCs. The mechanisms that produce this higher, warmer tropopause are currently being investigated in idealized simulations.

Acknowledgments. We are indebted to the entire TCI team for their efforts in obtaining the excellent dropsonde dataset used in this paper. We also acknowledge 
Yankee Environmental Systems for developing the HDSS dropsonde system and their cooperation throughout the TCI field campaign. We thank David Vollaro for determining the parallax offsets and for his assistance with dropsonde data processing. Dan Stern, Derrick Herndon, and Jason Dunion provided helpful insights during the preparation of this manuscript, and comments from three anonymous reviewers greatly improved a previous version. The dropsonde data used in this study are provided by the Earth Observing Laboratory of the National Center for Atmospheric Research. This work was supported by Office of Naval Research Grant N000141712110 as a part of the TCI Departmental Research Initiative.

\section{REFERENCES}

Bell, M. M., and Coauthors, 2016: ONR tropical cyclone intensity 2015 NASA WB-57 HDSS dropsonde data, version 1.0. UCAR/NCAR Earth Observing Laboratory, accessed 29 March 2016, doi:10.5065/D6KW5D8M.

Bister, M., and K. A. Emanuel, 1998: Dissipative heating and hurricane intensity. Meteor. Atmos. Phys., 65, 233-240, https:// doi.org/10.1007/BF01030791.

Black, P., L. Harrison, M. Beaubien, R. Bluth, R. Woods, A. Penny, R. W. Smith, and J. D. Doyle, 2017: High definition sounding system (HDSS) for atmospheric profiling. J. Atmos. Oceanic Technol., 34, 777-796, https://doi.org/10.1175/ JTECH-D-14-00210.1.

Braun, S. A., P. A. Newman, and G. M. Heymsfield, 2016: NASA's Hurricane and Severe Storm Sentinel (HS3) Investigation. Bull. Amer. Meteor. Soc., 97, 2085-2102, https://doi.org/ 10.1175/BAMS-D-15-00186.1.

Chen, H., and D.-L. Zhang, 2013: On the rapid intensification of Hurricane Wilma (2005). Part II: Convective bursts and the upper-level warm core. J. Atmos. Sci., 70, 146-162, https://doi.org/ 10.1175/JAS-D-12-062.1.

_ , and S. G. Gopalakrishnan, 2015: A study of the asymmetric rapid intensification of Hurricane Earl (2010) using the HWRF system. J. Atmos. Sci., 72, 531-549, https://doi.org/ 10.1175/JAS-D-14-0097.1.

Danielsen, E. F., 1993: In situ evidence of rapid, vertical, irreversible transport of lower tropospheric air into the lower tropical stratosphere by convective cloud turrets and by larger-scale upwelling in tropical cyclones. J. Geophys. Res., 98, 8665-8681, https://doi.org/10.1029/92JD02954.

Das, S. S., A. K. Patra, and D. N. Rao, 2008: VHF radar echoes in the vicinity of tropopause during the passage of tropical cyclone: First observations from the Gadanki MST radar. J. Geophys. Res., 113, D09113, doi:10.1029/2007JD009014.

_ pospheric ozone: Possible implications. Atmos. Chem. Phys., 16, 4837-4847, https://doi.org/10.5194/acp-16-4837-2016.

Davis, C. A., D. A. Ahijevych, J. A. Haggerty, and M. J. Mahoney, 2014: Observations of temperature in the upper troposphere and lower stratosphere of tropical weather disturbances. J. Atmos. Sci., 71, 1593-1608, https://doi.org/ 10.1175/JAS-D-13-0278.1.

Doyle, J. D., and Coauthors, 2017: A view of tropical cyclones from above: The Tropical Cyclone Intensity experiment. Bull.
Amer. Meteor. Soc., 98, 2113-2134, https://doi.org/10.1175/ BAMS-D-16-0055.1.

Dunion, J. P., 2011: Rewriting the climatology of the tropical North Atlantic and Caribbean Sea atmosphere. J. Climate, 24, 893-908, https://doi.org/10.1175/2010JCLI3496.1.

Duran, P., and J. Molinari, 2016: Upper-tropospheric low Richardson number in tropical cyclones: Sensitivity to cyclone intensity and the diurnal cycle. J. Atmos. Sci., 73, 545-554, https://doi.org/10.1175/JAS-D-15-0118.1.

Ebert, E. E., and G. J. Holland, 1992: Observations of record cold cloud-top temperatures in Tropical Cyclone Hilda (1990). Mon. Wea. Rev., 120, 2240-2251, https://doi.org/10.1175/ 1520-0493(1992)120<2240:OORCCT>2.0.CO;2.

Emanuel, K., 2012: Self-stratification of tropical cyclone outflow. Part II: Implications for storm intensification. J. Atmos. Sci., 69, 988-996, https://doi.org/10.1175/JAS-D-11-0177.1.

—_, and R. Rotunno, 2011: Self-stratification of tropical cyclone outflow. Part I: Implications for storm structure. J. Atmos. Sci., 68, 2236-2249, https://doi.org/10.1175/ JAS-D-10-05024.1.

, S. Solomon, D. Folini, S. Davis, and C. Cagnazzo, 2013: Influence of tropical tropopause layer cooling on Atlantic hurricane activity. J. Climate, 26, 2288-2301, https://doi.org/ 10.1175/JCLI-D-12-00242.1.

Ferreira, A. P., J. M. Castanheira, and L. Gimeno, 2016: Water vapour stratification and dynamical warming behind the sharpness of the Earth's midlatitude tropopause. Quart. J. Roy. Meteor. Soc., 142, 957-970, https://doi.org/10.1002/qj.2697.

Gentry, R. C., 1967: Structure of the upper troposphere and lower stratosphere in the vicinity of Hurricane Isbell, 1964. Pap. Meteor. Geophys., 18, 293-310, https://doi.org/10.2467/ mripapers1950.18.4_293.

Grise, K. M., D. W. J. Thompson, and T. Birner, 2010: A global survey of static stability in the stratosphere and upper troposphere. J. Climate, 23, 2275-2292, https://doi.org/10.1175/ 2009JCLI3369.1.

Guimond, S. R., G. M. Heymsfield, and F. J. Turk, 2010: Multiscale observations of Hurricane Dennis (2005): The effects of hot towers on rapid intensification. J. Atmos. Sci., 67, 633-653, https://doi.org/10.1175/2009JAS3119.1.

Halverson, J. B., J. Simpson, G. Heymsfield, H. Pierce, T. Hock, and L. Ritchie, 2006: Warm core structure of Hurricane Erin diagnosed from high altitude dropsondes during CAMEX-4. J. Atmos. Sci., 63, 309-324, https://doi.org/10.1175/JAS3596.1.

Haurwitz, B., 1935: The height of tropical cyclones and of the "eye" of the storm. Mon. Wea. Rev., 63, 45-49, https://doi.org/ 10.1175/1520-0493(1935)63<45:THOTCA > 2.0.CO;2.

Hawkins, H. F., and S. M. Imbembo, 1976: The structure of a small, intense hurricane-Inez 1966. Mon. Wea. Rev., 104, 418-442, https:// doi.org/10.1175/1520-0493(1976)104<0418:TSOASI >2.0.CO;2.

- and D. T. Rubsam, 1968: Hurricane Hilda, 1964. II. Structure and budgets of the hurricane on October 1, 1964. Mon. Wea. Rev., 96, 617-636, https://doi.org/10.1175/ 1520-0493(1968)096<0617:HH>2.0.CO;2.

Highwood, E. J., and B. J. Hoskins, 1998: The tropical tropopause. Quart. J. Roy. Meteor. Soc., 124, 1579-1604, https://doi.org/ 10.1002/qj.49712454911.

Hock, T. F., and J. L. Franklin, 1999: The NCAR GPS dropwindsonde. Bull. Amer. Meteor. Soc., 80, 407-420, https://doi.org/ 10.1175/1520-0477(1999)080<0407:TNGD>2.0.CO;2.

Holton, J. R., P. H. Haynes, M. E. McIntyre, A. R. Douglass, R. B. Hood, and L. Pfister, 1995: Stratosphere-troposphere exchange. Rev. Geophys., 33, 403-439, https://doi.org/10.1029/95RG02097. 
Jordan, C. L., 1958: Mean soundings for the West Indies area. J. Meteor., 15, 91-97, https://doi.org/10.1175/1520-0469(1958)015<0091: MSFTWI $>2.0 . \mathrm{CO} ; 2$.

, and E. S. Jordan, 1954: On the mean thermal structure of tropical cyclones. J. Meteor., 11, 440-448, https://doi.org/ 10.1175/1520-0469(1954)011<0440:OTMTSO > 2.0.CO;2.

Kieu, C., V. Tallapragada, D.-L. Zhang, and Z. Moon, 2016: On the development of double warm-core structures in intense tropical cyclones. J. Atmos. Sci., 73, 4487-4506, https://doi.org/ 10.1175/JAS-D-16-0015.1.

Kimberlain, T. B., E. S. Blake, and J. P. Cangialosi, 2016: Hurricane Patricia (20-24 October 2015). National Hurricane Center Tropical Cyclone Rep. EP202015, 32 pp., www.nhc.noaa.gov/ data/tcr/EP202015_Patricia.pdf.

Komaromi, W. A., and J. D. Doyle, 2017: Tropical cyclone outflow and warm core structure as revealed by HS3 dropsonde data. Mon. Wea. Rev., 145, 1339-1359, https://doi.org/10.1175/ MWR-D-16-0172.1.

Koteswaram, P., 1967: On the structure of hurricanes in the upper troposphere and lower stratosphere. Mon. Wea. Rev., 95, 541-564, https://doi.org/10.1175/1520-0493(1967)095<0541: $\mathrm{OTSOHI}>2.3 . \mathrm{CO} ; 2$.

Kuang, Z., and C. S. Bretherton, 2004: Convective influence on the heat balance of the tropical tropopause layer: A cloudresolving model study. J. Atmos. Sci., 61, 2919-2927, https:// doi.org/10.1175/JAS-3306.1.

La Seur, N. E., and H. F. Hawkins, 1963: An analysis of Hurricane Cleo (1958) based on data from research reconnaissance aircraft. Mon. Wea. Rev., 91, 694-709, https://doi.org/10.1175/ 1520-0493(1963)091<0694:AAOHCB > 2.3.CO;2.

Lazzara, M. A., and Coauthors, 1999: The Man Computer Interactive Data Access System: 25 years of interactive processing. Bull. Amer. Meteor. Soc., 80, 271-284, https://doi.org/ 10.1175/1520-0477(1999)080<0271:TMCIDA $>2.0$.CO;2.

Malkus, J. S., 1958: On the structure and maintenance of the mature hurricane eye. J. Meteor., 15, 337-349, https://doi.org/ 10.1175/1520-0469(1958)015<0337:OTSAMO > 2.0.CO;2.

Molinari, J., and D. Vollaro, 2010: Distribution of helicity, CAPE, and shear in tropical cyclones. J. Atmos. Sci., 67, 274-284, https://doi.org/10.1175/2009JAS3090.1.

_ , P. Duran, and D. Vollaro, 2014: Low Richardson number in the tropical cyclone outflow layer. J. Atmos. Sci., 71, 3164-3179, https://doi.org/10.1175/JAS-D-14-0005.1.

Mote, P. W., and Coauthors, 1996: An atmospheric tape recorder: The imprint of tropical tropopause temperature on stratospheric water vapor. J. Geophys. Res., 101, 3989-4006, https:// doi.org/10.1029/95JD03422.

Ohno, T., and M. Satoh, 2015: On the warm core of a tropical cyclone formed near the tropopause. J. Atmos. Sci., 72, 551-571, https://doi.org/10.1175/JAS-D-14-0078.1.

Pendergrass, A. G., and H. E. Willoughby, 2009: Diabatically induced secondary flows in tropical cyclones. Part I: Quasisteady forcing. Mon. Wea. Rev., 137, 805-821, https://doi.org/ 10.1175/2008MWR2657.1.

Penn, S., 1965: Ozone and temperature structure in a hurricane. J. Appl. Meteor., 4, 212-216, https://doi.org/10.1175/ 1520-0450(1965)004<0212:OATSIA > 2.0.CO;2.

- 1966: Temperature and ozone variations near tropopause level over Hurricane Isbell October 1964. J. Appl. Meteor., 5, 407-410, https:// doi.org/10.1175/1520-0450(1966)005<0407:TAOVNT>2.0.CO;2.

Randel, W. J., F. Wu, and P. Forser, 2007: The extratropical tropopause inversion layer: Global observations with GPS data, and a radiative forcing mechanism. J. Atmos. Sci., 64, 4489-4496, https://doi.org/10.1175/2007JAS2412.1.

Robinson, F. J., and S. C. Sherwood, 2006: Modeling the impact of convective entrainment on the tropical tropopause. J. Atmos. Sci., 63, 1013-1027, https://doi.org/10.1175/JAS3673.1.

Rogers, R. F., S. Aberson, M. M. Bell, D. J. Cecil, J. D. Doyle, J. Morgerman, L. K. Shay, and C. Velden, 2017: Rewriting the tropical record books: The extraordinary intensification of Hurricane Patricia (2015). Bull. Amer. Meteor. Soc., 98, 2091-2112, https://doi.org/10.1175/BAMS-D-16-0039.1.

Salby, M., and P. Callaghan, 2004: Control of the tropical tropopause and vertical transport across it. J. Climate, 17, 965-985, https://doi.org/10.1175/1520-0442(2004)017<0965: COTTTA $>2.0 . \mathrm{CO} ; 2$.

_ - F. Sassi, P. Callaghan, W. Read, and H. Pumphrey, 2003: Fluctuations of cloud, humidity, and thermal structure near the tropical tropopause. J. Climate, 16, 3428-3446, https://doi.org/ 10.1175/1520-0442(2003)016<3428:FOCHAT > 2.0.CO;2.

Schubert, W. H., C. M. Rozoff, J. L. Vigh, B. D. McNoldy, and J. P. Kossin, 2007: On the distribution of subsidence in the hurricane eye. Quart. J. Roy. Meteor. Soc., 133, 595-605, https://doi.org/10.1002/qj.49.

Seidel, D. J., R. J. Ross, J. K. Angell, and G. C. Reid, 2001: Climatological characteristics of the tropical tropopause as revealed by radiosondes. J. Geophys. Res., 106, 7857-7878, https://doi.org/10.1029/2000JD900837.

Sherwood, S. C., T. Horinouchi, and H. A. Zeleznik, 2003: Convective impact on temperatures observed near the tropical tropopause. J. Atmos. Sci., 60, 1847-1856, https://doi.org/ 10.1175/1520-0469(2003)060<1847:CIOTON $>2.0 . C O ; 2$.

Smith, R. K., 1980: Tropical cyclone eye dynamics. J. Atmos. Sci., 37, 1227-1232, https://doi.org/10.1175/1520-0469(1980)037<1227: TCED $>2.0 . C O ; 2$.

Stern, D. P., and D. S. Nolan, 2012: On the height of the warm core in tropical cyclones. J. Atmos. Sci., 69, 1657-1679, https:// doi.org/10.1175/JAS-D-11-010.1.

_ , and F. Zhang, 2013: How does the eye warm? Part I: A potential temperature budget analysis of an idealized tropical cyclone. J. Atmos. Sci., 70, 73-89, https://doi.org/10.1175/JAS-D-11-0329.1.

University of Wyoming, 2016: Atmospheric Soundings. University of Wyoming, accessed 6 April 2016, http://weather.uwyo.edu/ upperair/sounding.html.

Waco, D. E., 1970: Temperatures and turbulence at tropopause levels over Hurricane Beulah (1967). Mon. Wea. Rev., 98 , 749-755, https://doi.org/10.1175/1520-0493(1970)098<0749: TATATL $>2.3 . \mathrm{CO} ; 2$.

Willoughby, H. E., 1979: Forced secondary circulations in hurricanes. J. Geophys. Res., 84, 3173-3183, https://doi.org/10.1029/ JC084iC06p03173.

Wirth, V., 2003: Static stability in the extratropical tropopause region. J. Atmos. Sci., 60, 1395-1409, https://doi.org/10.1175/ 1520-0469(2003)060<1395:SSITET > 2.0.CO;2.

Yuter, S. E., and R. A. Houze Jr., 1995: Three-dimensional kinematic and microphysics evolution of Florida cumulonimbus. Part II: Frequency distributions of vertical velocity, reflectivity, and differential reflectivity. Mon. Wea. Rev., 123, 1941-1963, https://doi.org/10.1175/1520-0493(1995)123<1941: TDKAME $>2.0 . \mathrm{CO} ; 2$

Zhang, D.-L., and H. Chen, 2012: Importance of the upper-level warm core in the rapid intensification of a tropical cyclone. Geophys. Res. Lett., 39, L02806, https://doi.org/10.1029/ 2011 GL050578. 